\title{
Application of Regression Method for Determining the Die Land Dimensions based on Data from Industry
}

Velibor Marinković

Full Professor

University of Niš

Faculty of Mechanical Engineering

Predrag Janković

Associate Professor

University of Niš

Faculty of Mechanical Engineering
The closed-die forging is a quite complicated forming process that is affected by a large number of forming factors (such as dimensions and shape complexity of the forged part, mass and shape of raw material (billet), forging die geometry, material properties etc.).

In the forging process/die design the choice of the appropriate die land geometry is a difficult and very important task. In this study, the new equations for determining the die land dimensions have been developed by using the regression analysis. The input-output data set was constructed on the basis of the samples from industry. The validation of derived equations was carried out with a case study. These equations can be used for any kind of an axisymmetrical forged part.

Proposed equations offer forging process/die designers the possibility to choose the die land dimensions more precisely. In that way, the reduction of the expensive and time consuming trial-and-error procedure in industrial practice is real and possible. On the other hand, determining the proper (optimal) dimensions of die land leads to a successful forging process. Consequently, less mass of raw material, reduction of forging load/work, less die wear as well as best quality of forging parts should be achieved.

Keywords: closed-die forging, die land, regression analysis

\section{INTRODUCTION}

Closed-die forging (with flash) is one of the oldest and most common forming technologies for manufacturing the finished and semi-finished products. Closed-die forging has many advantages: good utilization of material, better material properties (strength and toughness), good reproducibility, high productivity (small production time), acceptable tolerances and accuracy, large production quantities, and so on. Some of the shortcomings are present as well: high production costs, expensive dies and equipment, high consumption of energy (deformation work for forging and other operations, heating billets and preheating dies), necessity of more than one die to complete the forging process, high material costs, requirements for industrial experience and skills, the need for subsequent processing (trimming, piercing, machining), long time for forging dies / forging process designing, etc.

More than four million tons of forging parts were produced in 2012 in Europe and more than 18 million tons worldwide. About $70 \%$ of the parts produced in Europe were forged by closed-die forging [1].

For this forming technology it is characteristic that the volume of the forged part/billet is greater than the volume

Accepted: February 2017, Received: April 2017

Correspondence to: Dr Velibor Marinković

Faculty of Mechanical Engineering,

A.Medvedeva 14, 18000 Niš, Serbia

E-mail: velmar@masfak.ni.ac.rs

doi:10.5937/fmet1704590M

(c) Faculty of Mechanical Engineering, Belgrade. All rights reserved of the finished part. Excess material is a consequence of inaccuracy while determining mass (volume) of the raw material with respect to the mass of the pure forged part as well as the tendency to do complete filling of the die cavity. Namely, additional mass of the raw material is necessary in order to guarantee the absence of underfilled hollows in the die cavity.

The final filling of the die cavity is ensured not earlier than the excess material starts to flow through die land (throat) into the gutter. In the beginning, material flows outside of the die cavity so the width of the flash continually increases, while its thickness decreases. Consequently, the deformation resistance and friction forces at the die land area increase. When the excess material gets to the gutter, further resistance increase is obtained only by reducing the flash thickness. That represents the last phase of the forging process where the material (in accordance with the law of least resistance) changes the direction of the material flow. Namely, material flow in radial direction is predominantly replaced by material flow in the axial direction, and in this way the remaining hollows in the forging die are filled.

\section{INFLUENCE OF DIE LAND GEOMETRY ON FORGING PROCESS}

It is well known that the excess volume of the billet does not by itself assure the filling of the die cavity. If the flash thickness is too large and/or flash width too small, the die cavity may not be fulfilled, in spite of the fact that the flash has been predicted. In such cases, the 
material from the die cavity will flow outward too easily (with very low resistance).

It can be observed that the die land is a distinctive element of the forging die, as the most responsible for the whole filling of the die cavity, especially for forged parts with tight ribs, small external/internal draft angles and small fillet/corner radii. In such forging conditions, it is not possible to perform closed-die forging process in one operation. Multiple dies and multistage forging process are necessary. Desired quality and accuracy of the forged parts can be obtained in a multiforging sequence with one or more preform stages (blocking, edging, fullering) and final forging.

As mentioned earlier, the excess material flows through the die land into a specially designed gutter. In industrial practice closed-dies with parallel die land and one-sided gutter are mainly used, rather than one of the other kinds of die lands (Figure 1).

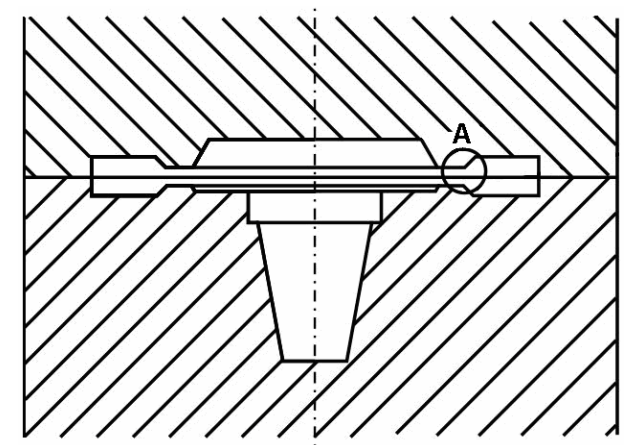

Detail A

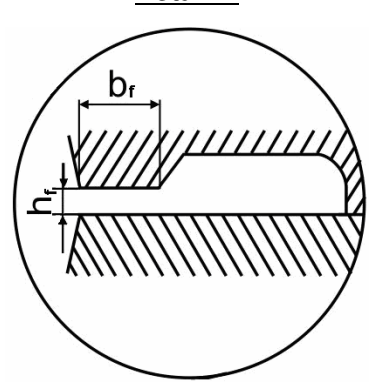

Figure 1. General design of forging die

After the forging process is finished, the flash is subsequently removed from the forged part in the special trimming tool [2].

The peak forging load is achieved when the top die reaches its lowest position. In other words, the thinner the flash is, the higher the forging load is.

An optimal design of the die land area allows avoiding defects within forged parts (shuts, laps, folds, internal cracks, and other damages).

The amount of primary scrap in the form of flash is estimated at about $20 \%$ of the entire volume of the forged part and, thus, should be reduced as much as possible. Generally, the quantity of the excess material can serve as a quality criterion of the designed forging process.

Theoretical analysis and industrial practice have confirmed many other important functions of the die land in the forging process.

The value and gradient of the forging load and, at the same time, forging work, depend to a great extent on the die land design (Figure 2.) [2], [3].
Also, the die land shape and dimensions influence essentially the die wear i.e. its durability (die life) and production costs as well as the quality of the forged parts. Among the other types of failures (such as adhesion wear, thermo-mechanical fatigue and plastic deformation), abrasive wear is the predominant degradation mechanism in closed-die forging. Abrasive die wear is high due to the intensive flow of the material in the presence of abrasive oxide particles and die bits [4], [5]. Consequently, abrasive die wear is the main reason for failures in the forging die, despite the fact that many of the above mentioned phenomena occur simultaneously. On the other hand, nitriding, hard coating, boriding and other techniques may improve die wear resistance [6].

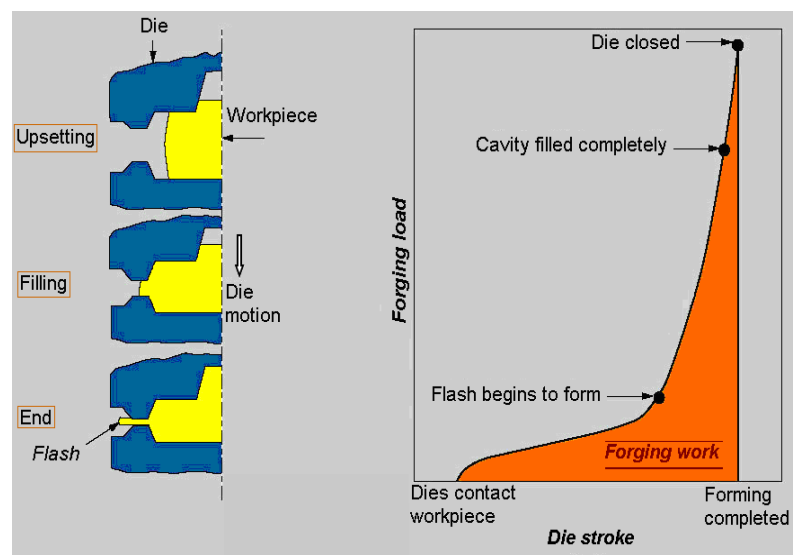

Figure 2. Effect of geometrical parameters of die land on forging load/ forging work (According to [2])

Generally, increasing the die life can be achieved by a combination of optimal forging die/proces design, appropriate thermal and tribological conditions as well as improvements in die material properties.

It is reasonable to assume that the forging die/process designers in the industry should keep in mind the previously mentioned influences as quality criteria for determining the proper (optimal) geometrical parameters of the die land.

In this research, the main attention is focused on determining the geometrical parameters of the die land in the closed-die forging process.

\section{MODELING OF DIE LAND GEOMETRY}

Here are some of the well-known existing equations concerning the calculation of the die land dimensions for forging on hammers (drop forging), [7], [8]:

a) Wolf H.,

$$
\begin{aligned}
& h_{f}=1.13+0.89 \sqrt{m_{f}}-0.017 m_{f} \\
& \frac{b_{f}}{h_{f}}=3+1.25 \exp \left(-1.09 m_{f}\right)
\end{aligned}
$$

b) Voigtlander O.,

$$
\begin{gathered}
h_{f}=0.016 D_{f} \\
\frac{b_{f}}{h_{f}}=\frac{63}{\sqrt{D_{f}}}
\end{gathered}
$$


c) Vieregge K.,

$$
\begin{gathered}
h_{f}=0.017 D_{f}+\frac{1}{\sqrt{D_{f}+5}} \\
\frac{b_{f}}{h_{f}}=\frac{30}{\sqrt[3]{D_{f}\left[1+\frac{2 D_{f}^{2}}{H_{f}\left(2 R_{f, c}+D_{f}\right)}\right]}}
\end{gathered}
$$

d) Tichkiewitch E.N.S.,

$$
\begin{gathered}
b_{f}=\left\{\begin{array}{l}
0.04285 D_{f}+3.4285, \text { for } D_{f}<200 \mathrm{~mm} \\
0.025 D_{f}+7 \quad, \text { for } D_{f}>200 \mathrm{~mm}
\end{array}\right. \\
\frac{b_{f}}{h_{f}}=0.514\left(H_{r} / E_{r}\right)+4.2114
\end{gathered}
$$

e) Teterin G.P.,

$$
\begin{gathered}
h_{f}=-0.09+2 \sqrt[3]{m_{f}}-0.01 m_{f} \\
\frac{b_{f}}{h_{f}}=-0.02+0.0038 S_{r}+\frac{4.93}{m_{f}^{0.2}} ; S_{r}=S D_{0} / h_{f}
\end{gathered}
$$

where $h_{f}[\mathrm{~mm}]$ is the height of the die land, $b_{f}[\mathrm{~mm}]$ is the width of the die land, $m_{f}[\mathrm{~kg}]$ is the mass of the forged part, $D_{f}[\mathrm{~mm}]$ is the diameter of the forged part (without flash), $H_{f}[\mathrm{~mm}]$ is the height of the forged part, $R_{f, c}[\mathrm{~mm}]$ is the distance from the center of gravity of the half longitudinal cross-section to the axis of symmetry of the forged part, $S_{r}$ is the relative degree of shape complexity, $S$ is the degree of shape complexity, $D_{0}[\mathrm{~mm}]$ is the diameter of the cylindrical billet, $H_{r}$ [mm] is the height of the rib, $E_{r}[\mathrm{~mm}]$ is the width of the rib.

The degree of shape complexity by forging is defined as the following relation:

$$
S=S_{f} / S_{b}
$$

where $S_{f}$ is the degree of complexity of the forged part, $S_{b}$ is the degree of complexity of the billet or perform part.

The relation (7) defines the degree of complexity of the forged part [9]:

$$
S_{f}=\frac{\left(V^{2} / A\right)_{f}}{\left(V^{2} / A\right)_{f, c}} \frac{2 R_{f, c}}{R_{f}}
$$

where $\left(V^{2} / A\right)_{f}$ is the ratio of volume squared and area of the longitudinal cross-section of the forged part, $\left(V^{2} / A\right)_{f, c}$ is the ratio of volume squared and area of the longitudinal cross-section of the circumscribing cylinder around the forged part, $R_{f}[\mathrm{~mm}]$ is the radius of the forged part $\left(R_{f}=0.5 D_{f}\right)$.

For cylindrical billets $S_{b}=1$, so that $S \equiv S_{f}$.

The approximate degree of shape complexity by forging can be taken from Figure 3 [9].

All above equations comprise the impact of only one or two forming factors (mass and /or dimensions of the forged part). It should be noted that Teterin introduces the impact of dimensions of the forged part through a relative degree of complexity $\left(S_{r}\right)$.

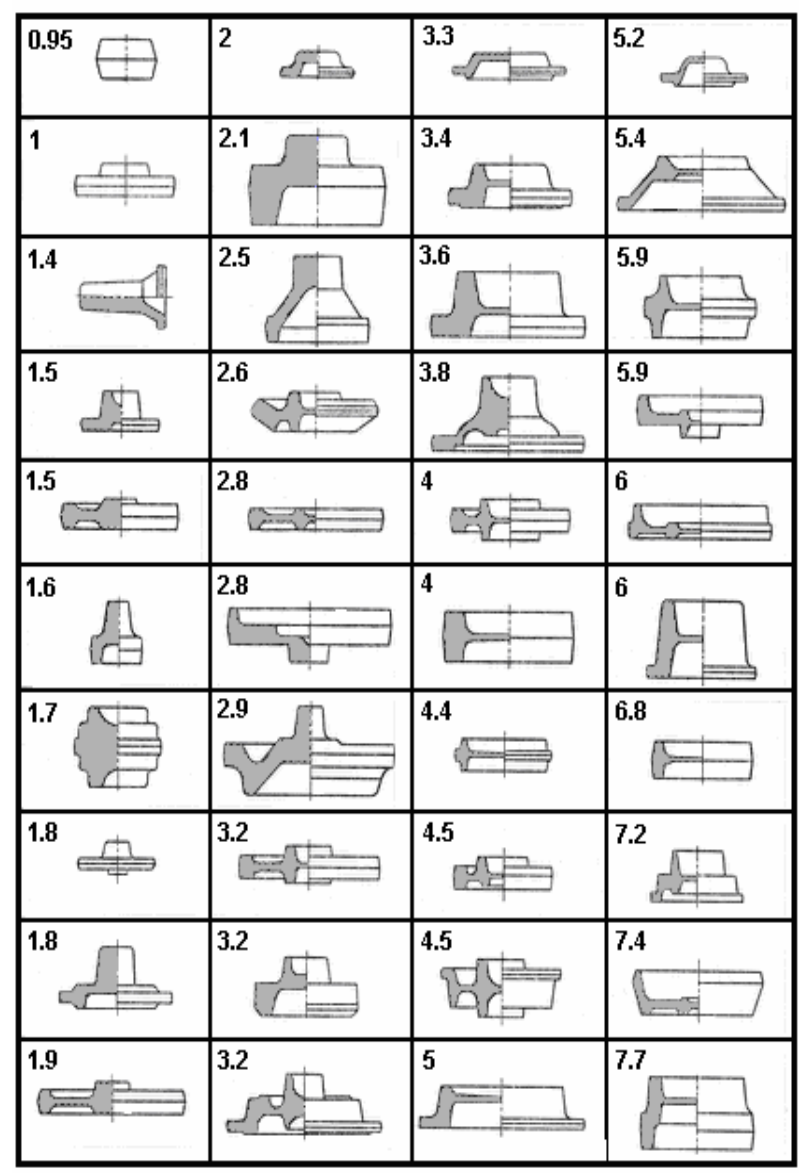

Figure 3. Degree of shape complexity

In this paper the choice of the geometrical parameters of the die land was based on three important forming factors (Table 1).

In this case, the forming factors (input variables, independent variables) are distributed in wide ranges $\left(D_{f} / H_{f} \cong 1.5\right.$ to $7.5 ; m_{f} \cong 1$ to $450 ; S D_{0} / h_{f} \cong$ $\cong 23$ to 485 ).

The same goes for die land dimensions (output variables,dependent variables, responses) $h_{f} \cong 1.5$ to 12 ; $b_{f} / h_{f} \cong 2$ to 5 ).

The accuracy and consistency of the regression analysis depends on the data set used. The distribution of the input data within a corresponding range can be depicted in intervals where higher or lower accuracy of derived regression equations should be expected.

Figure 4 presents the distributions of the input data set as histograms in ten equal ranges between the minimum and maximum values.

As shown in Figure 4, the distributions of the input data set are characterized by void zones and clusters with high data density. Also, the patterns in these histograms are skewed and partly bimodal, and deviate from the law of normal distribution (for each input variable), which more readily deals with mathematical modeling to achieve a better prediction. The regression equation is expected to be more accurate at the intervals of high data density and vice versa. 
Table 1. Input-output data for regression analysis

\begin{tabular}{|c|c|c|c|c|}
\hline $\mathrm{x}_{1}=\mathrm{D}_{\mathrm{f}} / \mathrm{H}_{\mathrm{f}}$ & $\mathrm{x}_{2}=\mathrm{m}_{\mathrm{f}}$ & $\mathrm{x}_{3}=\mathrm{S}_{\mathrm{r}}$ & $\mathrm{y}_{1}=\mathrm{h}_{\mathrm{f}}$ & $\mathrm{y}_{2}=\mathrm{b}_{\mathrm{f}} / \mathrm{h}_{\mathrm{f}}$ \\
\hline 3.427 & 6.7 & 90.00 & 4.22 & 3.569 \\
\hline 6.325 & 23.5 & 138.00 & 5.15 & 3.466 \\
\hline 4.686 & 109.1 & 94.50 & 9.59 & 1.928 \\
\hline 4.739 & 10.3 & 176.34 & 4.37 & 3.558 \\
\hline 3.046 & 16.0 & 148.10 & 4.96 & 3.312 \\
\hline 4.051 & 22.0 & 132.00 & 4.94 & 3.318 \\
\hline 7.516 & 33.0 & 231.50 & 5.17 & 3.911 \\
\hline 5.086 & 192.1 & 330.00 & 7.85 & 2.795 \\
\hline 3.293 & 117.0 & 235.40 & 8.28 & 2.646 \\
\hline 4.261 & 43.0 & 119.00 & 8.07 & 2.711 \\
\hline 4.833 & 195.1 & 239.40 & 10.05 & 2.084 \\
\hline 5.189 & 379.7 & 155.20 & 12.12 & 1.971 \\
\hline 3.157 & 4.0 & 65.20 & 3.00 & 4.253 \\
\hline 2.512 & 1.6 & 68.40 & 1.85 & 5.292 \\
\hline 1.487 & 5.3 & 23.20 & 3.17 & 3.536 \\
\hline 2.464 & 2.7 & 51.30 & 2.45 & 4.204 \\
\hline 2.988 & 3.2 & 50.90 & 3.12 & 4.003 \\
\hline 1.475 & 13.5 & 52.50 & 3.72 & 3.277 \\
\hline 4.622 & 4.9 & 71.40 & 2.78 & 4.460 \\
\hline 2.829 & 64.0 & 153.50 & 8.93 & 1.950 \\
\hline 4.245 & 84.0 & 213.60 & 7.85 & 2.795 \\
\hline 4.088 & 49.5 & 168.20 & 5.62 & 3.153 \\
\hline 4.487 & 21.4 & 139.40 & 4.51 & 3.459 \\
\hline 6.372 & 19.0 & 286.10 & 5.18 & 4.019 \\
\hline 3.653 & 17.0 & 116.30 & 5.05 & 3.285 \\
\hline 2.263 & 2.1 & 67.90 & 2.11 & 4.635 \\
\hline 4.248 & 0.9 & 88.90 & 1.43 & 6.923 \\
\hline 2.652 & 3.0 & 61.10 & 3.10 & 3.897 \\
\hline 2.088 & 1.87 & 42.70 & 2.24 & 4.295 \\
\hline 2.180 & 2.1 & 88.20 & 1.85 & 5.265 \\
\hline 3.180 & 264.9 & 146.20 & 10.79 & 1.930 \\
\hline 2.259 & 449.9 & 67.74 & 9.93 & 1.899 \\
\hline 2.219 & 42.2 & 484.90 & 5.21 & 3.733 \\
\hline
\end{tabular}

This type of distribution is typical with the data from real industrial processes. It should be noted that the entire input-output data set was created from direct manufacturing (from forging companies) [9]. For that reason, the available data set is not high-quality in the statistical sense.

Also, preliminary analysis has shown that some of the data may be treated as outliers [10].

The main disadvantage of the standard regression analysis (by using least-square approach) is its sensitivity to outliers. Outliers have a great influence on the fitting procedure, because squaring the residuals magnifies the effects of these extreme data points. Statistically, in such a case the given data set is not good enough. For that reason, in this research the original geometrical parameters of the die land were previously optimized (generalized) by using artificial neural network [11].

The relationship between input and output parameters was established by applying the standard regression analysis. Note, for the active experiment it is much more efficient to apply the design of experiment (DoE) methodology [10,12].

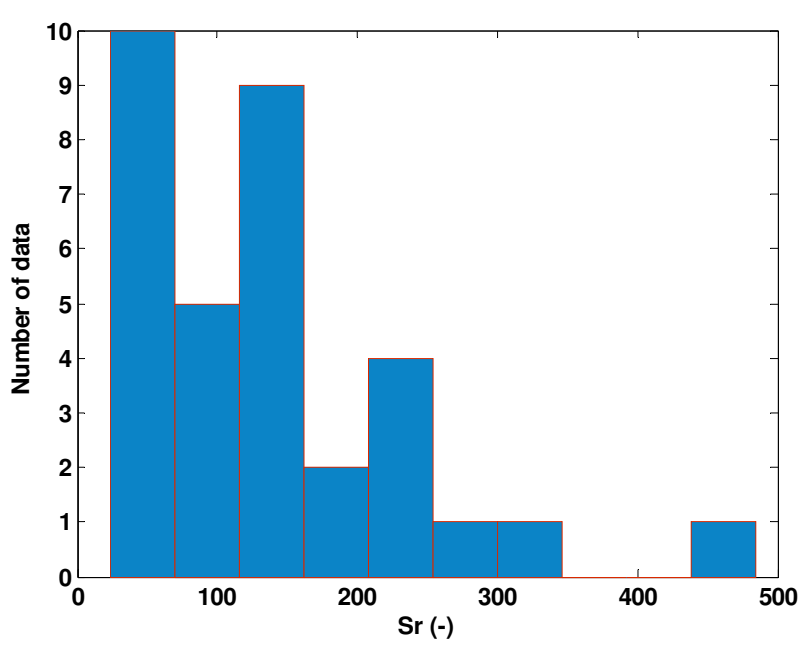

a)

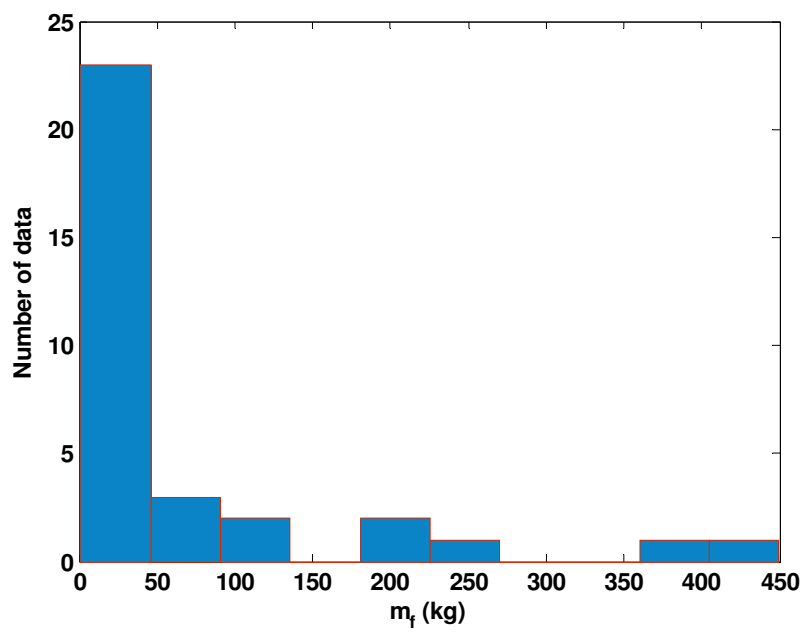

b)

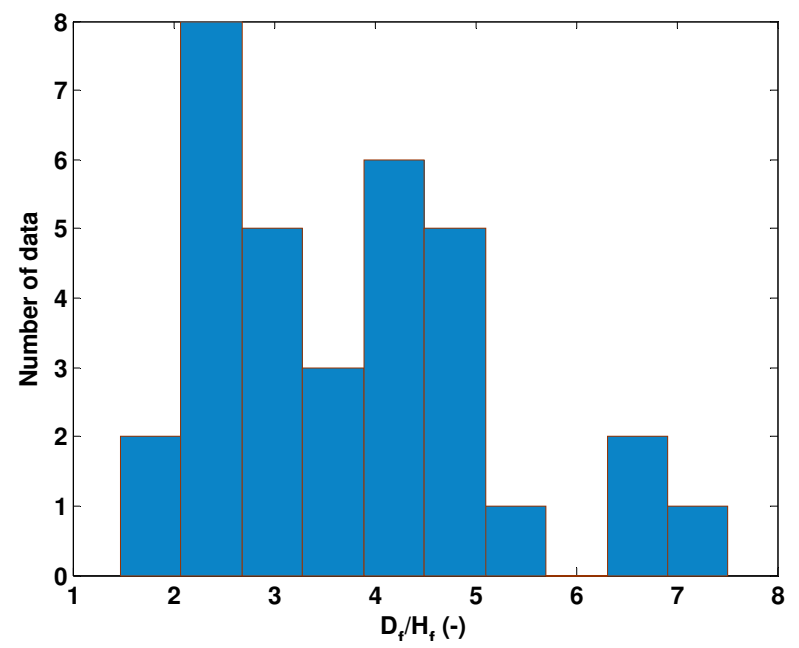

c)

Figure 4. Input data distribution for: (a) relative degree of shape complexity, (b) mass of the forged part, (c) overall dimensions of the forged part.

The success of a regression analysis depends largely on the choice of appropriate mathematical models. Based on the previous analysis of statistical data, the following relationships in the form of the multiple power functions were established:

$$
h_{f}=C_{1}\left(D_{f} / H_{f}\right)^{n_{1}} m_{f}^{n_{2}} S_{r}^{n_{3}}
$$




$$
b_{f} / h_{f}=C_{2}\left(D_{f} / H_{f}\right)^{m_{1}} m_{f}^{m_{2}} S_{r}^{m_{3}}
$$

where $C_{1}, C_{2}, n_{1}, n_{2}, n_{3}, m_{1}, m_{2}, m_{3}$ are the constants to be determined by means of the regression method. In terms of statistical analysis both $h_{f}$ and $b_{f} / h_{f}$ are the estimated responses.

In this case, the selected mathematical model provides the most appropriate approximation of the given experimental data. In general, the mathematical models can also include factor interactions. Since the impact of factor interactions is usually negligible, these terms of the mathematical model may be omitted [13].

Applying the logarithmic transformation, the nonlinear equations (8) can be converted into the linear equations. After that, the parameters of Eqs. (8) have been estimated by means of the least-square procedure, using the Matlab software package. In this way, the following multiple regression equations were obtained:

$$
\begin{aligned}
& h_{f}=2.0726\left(D_{f} / H_{f}\right)^{0.1109} m_{f}^{0.3244} S_{r}^{-0.0582} \\
& b_{f} / h_{f}=2.7420\left(D_{f} / H_{f}\right)^{0.0362} m_{f}^{-0.2064} S_{r}^{0.1591}
\end{aligned}
$$

For the forging process/die designers in practice it is much more comfortable that the above equations are shown as follows:

$$
\begin{gathered}
h_{f}=2.1681\left(D_{f} / H_{f}\right)^{0.1178} m_{f}^{0.3444}\left(S D_{0}\right)^{-0.0618}(10 \mathrm{a}) \\
b_{f} / h_{f}=2.4246\left(D_{f} / H_{f}\right)^{0.0175} m_{f}^{0.2612}\left(S D_{0}\right)^{0.1689}(10 \mathrm{~b})
\end{gathered}
$$

\section{A CASE STUDY}

Figure 5 presents the shape of forged part for a representative gear wheel [14]. The initial billet was of cylindrical shape with a diameter equal to $70[\mathrm{~mm}]$ and a height equal to 155 [mm]. The mass of the forged part was equal to $4[\mathrm{~kg}]$. The overall dimensions of the forged part $D_{f} x H_{f}$ were equal to $183 \times 48\left[\mathrm{~mm}^{2}\right]$.

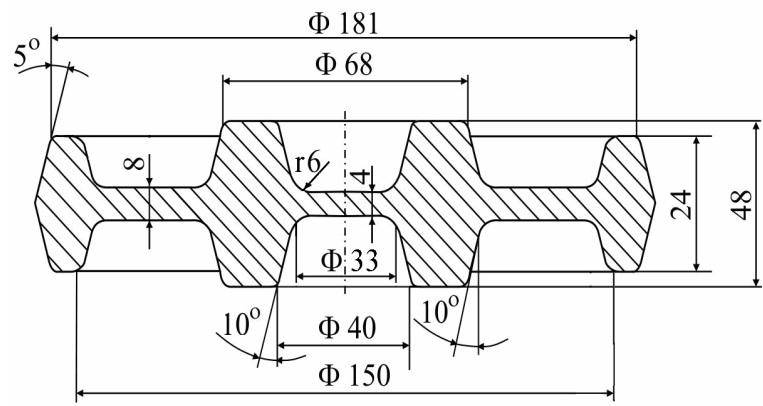

Figure 5. Forged part (after flash trimming)

The forging die designer was chosen for the following die land dimensions: $h_{f}=3[\mathrm{~mm}]$ and bf $=12$ [mm]. In that case, the ratio $b_{f} / h_{f}$ is equal to 4.0 .

For this particular forged part the degree of shape complexity by forging is equal to 4 , approximately (see Figure 3).

After applying equations (10), the following results were obtained:

$$
\begin{array}{r}
\mathrm{hf}=2.9[\mathrm{~mm}] ; b_{f} / h_{f}=4.4 \\
(\mathrm{bf}=4.4 \cdot \mathrm{hd}=4.4 \cdot 2.9=12.7[\mathrm{~mm}])
\end{array}
$$

Nearly the same values (coordinates) can be found in the diagram in Figure 6. For instance: $h_{f}=3[\mathrm{~mm}]$ and $b_{f} / h_{f}=4.2$ (with deviations less than $\pm 5 \%$ in relation to the calculated values).

However, after applying in the literature often quoted equations (3), the following results were obtained:

$$
\begin{gathered}
h_{f} \cong 3.2[\mathrm{~mm}] ; b_{f} / h_{f} \cong 2.9 \\
\left(b_{f}=2.9 h_{f}=2.9 \cdot 3.2=9.9[\mathrm{~mm}]\right)
\end{gathered}
$$

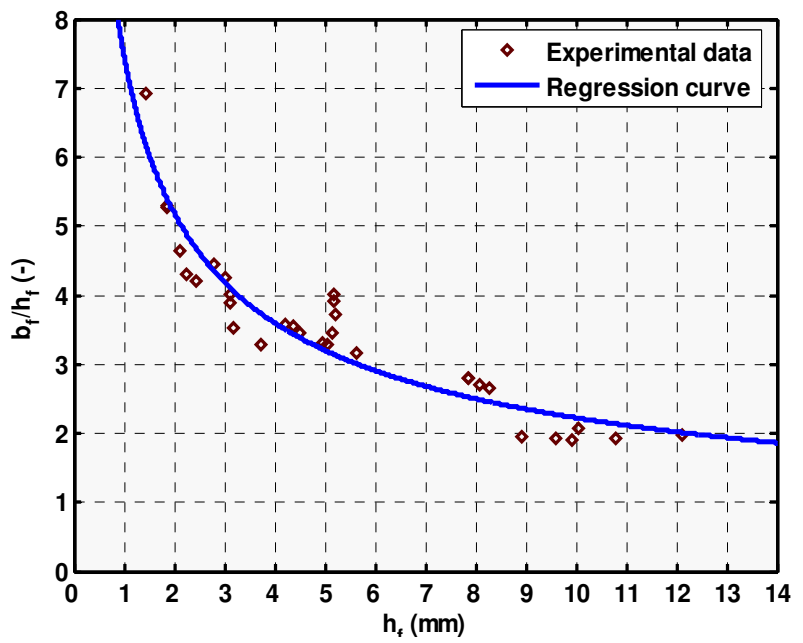

Figure 6. Interdependence of die land dimensions

\section{RESULTS AND DISCUSSION}

For determining the errors of calculation the following criteria were used: mean percentage error $(\bar{\delta})$, and mean absolute percentage error $(\bar{\Delta})$ :

$$
\begin{gathered}
\bar{\delta}=\frac{1}{n} \sum_{i=1}^{n} \frac{y_{i, c a l}-y_{i, \exp }}{y_{i, \exp }} 100[\%] \\
\bar{\Delta}=\frac{1}{n} \sum_{i=1}^{n}\left|\frac{y_{i, c a l}-y_{i, \exp }}{y_{i, \exp }}\right| 100[\%]
\end{gathered}
$$

where $n$ is the number of trials in the experiment, $y_{i, c a l}$ are the calculated values, and $y_{i, \exp }$ are the experimental values.

The results obtained by applying Eqs. (11) for the given data set are inserted into Table 2.

Table 2. Errors and correlation coefficient

\begin{tabular}{|c|c|c|c|}
\hline & $\bar{\delta}[\%]$ & $\bar{\Delta}[\%]$ & $R$ \\
\hline$h_{f}$ & 0.428 & 10.498 & 0.957 \\
\hline$b_{f} / h_{f}$ & 0.394 & 8.075 & 0.956 \\
\hline
\end{tabular}

The accuracy of any empirical model can also be done by means of the correlation coefficient ( $R$ ). The correlation coefficient is a statistical measure of the strength of correlation between the predicted and experimental values. For the current problem, the computed correlation coefficients are also presented in Table 2 .

Under the given circumstances, the discrepancies between calculated and actual values are quite 
acceptable. Due to the above mentioned reasons, single larger deviations are possible. However, in general, the accuracy and reliability of the proposed formulae are good enough for the purposes of the calculation in the forging manufacturing.

The prediction by using the proposed equations in this study has an associated mean absolute error much lower than the one obtained by the existing semiempirical formulae.

Strictly speaking, the derived equations are valid for the given experimental space, because it is very possible that a regression model that fits well in the space of the original data will no longer fit well outside of that space.

After the analysis of the obtained equations, it can be stated, that the die land height monotonically increases with an increase in $D_{f} / H_{f}$ and $m_{f}$, because the coefficients for these forming factors are positive, whereas the coefficient for degree of shape complexity is negative, indicating a monotonically decreasing tendency of the die land height with the increasing $S_{r}$.

On the other hand, the die land width (i.e. $b_{f} / h_{f}$ ratio) monotonically increases with an increase in $D_{f} / H_{f}$ and $S_{r}$, whereas it monotonically decreases with an increase in $m_{f}$.

It is interesting to observe that the mass of the forged part and the degree of shape complexity affect the die land dimensions in the opposite directions.

The absolute contribution of the three forming factors can be ranked as follows: relativelly small $D_{f} / H_{f}$, medium - $S_{r}$, and large $-m_{f}$.

Altough the forged part dimensions affect the die land dimensions to a relatively small extent (up to $5 \div 20 \%$ approximatelly), they can not be ignored.

It is easy to prove that the assumption regarding the absence of interactions between the forming factors was valid.

The relative width of the die land can be set up by correction of the forging die and /or by adjusting of the gap between the top and bottom dies. For this purpose, the graph in Figure 6 can be useful to designers of the forging dies in the industry.

For this purpose, the application of physical modeling and numerical simulation (FEM) can be very successfully [4], [15-18]. Also, the recent research regarding the construction of non-traditional shapes of die land should be pointed to [18, 19].

Finally, a cost analysis can be carried out in order to examine the effects of the selected die land geometry on the forging process costs.

\section{CONCLUSION}

It can be stated that the die land geometry has a decisive role for an adequate distribution of material at the end of the forging process. When the proper (optimal) die land design is determined, the die cavity will be filled completely and the amount of waste material will be minimal. In such a case, required energy and forging load are less as well as wear of the forging die.

The improved equations for the die land dimensions developed in this research were based on a large industrial data set.
The calculation by using the obtained regression equations are in very good agreement with the experimental data.

It is belived that the equations and analysis derived in this research can be used as a practical guide for selectiing an appropriate die land design in order to achieve the desired forging process performance and quality of the forged products.

The mathematical model utilized in this research may be the subject of further developement and improvement. It can be carried out by using new arrangements of input data and/or more complex mathematical models.

\section{ACKNOWLEDGMENT}

The paper is a result of the technological project TR35034 which is supported by the Ministry of Education, Science and Technological Development of the Republic of Serbia.

\section{REFERENCES}

[1] Langner, J., Stonis, M., Behrens, B.-A.: Experimental investigation of a variable flash gap regarding material flow and influence of trigger forces, Production Engineering. Research and Development. Vol. 9, pp. 289-297, 2015.

[2] Kalpakjian, S., Schmid, S.: Engineering and Technology, Fifth Edition, Pearson Education, New York, 2006.

[3] Spur, G., Schmoeckel, D.: Handbuch der Fertigungstechnik, Umformen, Carl Hanser Verlag, München/Wien, 1984. (in German).

[4] Iamtanomchai R., Bland S.: Study of Wear and Life Enhancement of Hot Forging Dies Using Finite Element Analysis. Proceedings of the World Congress on Engineering, London, Vol. II, 2015.

[5] Gronostajski, Z., Kaszuba, M., Polak, S., Zwierzchowski, M., Niechajowicz, A., Hawryluk, M.: The failure mechanisms of hot forging dies, Materials Science \& Engineering A, Vol. 657, pp. 147-160, 2016.

[6] Arsić, D. et al.: Impact of the hard facing technology and the filler metal on tribological characteristics of the hard faced forging dies. Tehnički Vjesnik-Technical Gazette, Vol. 22, No 5, pp.1353-1358, 2015.

[7] Sleeck, E., Kruth, J.P.: Review of flash design rules for closed-die forgings. Journal of Material Processing Technology, Vol. 31, pp.119-134, 1992.

[8] Tomov, B., Radev, R., Gagov, V.: Influence of flash design upon process parameters of hot die forging. Journal of Material Processing Technology, Vol. 157-158, pp. 620-625, 2004.

[9] Teterin, G.P., Polukhin, P.I.: Basics of optimization and automatization of the technological processes design in hot bulk stamping "Mashinostroenie“, Moscow, 1979. (in Russian).

[10] Montgomery, D.C.: Design and analysis of experiments. John Wiley \& Sons, New York, 2005. 
[11] Marinkovic, V.: Application of artificial neural network for modeling the flash land dimensions in the forging dies. Journal of Mechanical Engineering, Vol. 55, pp. 64-75, 2009.

[12] Marinkovic, V.: Prediction of flow stress of alloyed steel in hot forming by applying different mathematical models and design of experiment. Journal for Technology of Plasticity, Vol.36, No 2, pp. 71-86, 2011.

[13] Lazarevic, A., Marinkovic, V., Lazarevic, D.: Expanded non-linear mathematical models in the theory of experimental design, RaDMI 2010, pp. 304-310, 2010.

[14] Semenov, E.I.: Forging and bulk forming, „Vishaja shkola“, Moscow, 1992. (in Russian).

[15] Radev, R.: Numerical investigations regarding necessity of preforming steps for hot closed die forging of axisymmetrical parts. Journal for Technology of Plasticity, Vol. 38, No 2, pp. 125$131,2013$.

[16] Bramley, A.N., Mynors, D.J.: The use of forging simulation tools. Materials and Design, Vol. 21, pp. 279-286, 2000.

[17] Vazquez, V., Altan, T.: New concepts in die design -physical and computer modeling applications. Journal of Material Processing Technology, Vol. 98, pp. 212-223, 2000.

[18] Samolyk, S., Pater, Z.: Use of SLFET for design of flash gap with $\mathrm{V}$-notched lands in a closed-die forging. Journal of Material Processing Technology, Vol. 162-163, pp. 558-563, 2005.

[19] Sedighi, M., Pourbashiri, M.: Variable gutter technique as a novel method to reduce waste material in closed die-forging process. Journal of
Mechanical Science and Technology, Vol. 28, Issue 12, pp. 5129-5134, 2014.

\section{ПРИМЕНА РЕГРЕСИОНОГ МЕТОДА ЗА ОДРЕБИВАЊЕ ДИМЕНЗИЈА МОСТИЋА КОВАЧКОГ АЛАТА ЗАСНОВАНА НА ПОДАЦИМА ИЗ ИНДУСТРИЈЕ}

\section{В. Маринковић, П. Јанковић}

Ковање у отвореном алату је доста сложен процес деформисања, који зависи од великог броја фактора деформисања (као што су: димензије и сложеност облика отковка, маса и облик сировог материјала (припремка), геометрија ковачког алата, својства материјала итд.).

При пројектовању ковачког процеса/алата избор погодне геометрије мостића је тежак и врло важан задатак.

У овој студији су развијене нове једначине за одређивање димензија мостића алата применом регресионе анализе. Улазно-излазни сет података је креиран на основу узорака из индустрије.

Провера изведених једначина је изведена на једном примеру. Ове једначине се могу користити за сваку врсту осносиметричних отковака.

Препоручене једначине нуде пројектантима ковачког процеса/алата могућност да много тачније изаберу димензије мостића ковачког алата. На тај начин је реална и могућа редукција скупог "пробагрешка“ поступка у индустријској пракси. Сагласно томе може се остварити мања маса сировог материјала, смањење силе/рада ковања, мање хабање алата, као и бољи квалитет отковака. 